Article

\title{
Impacts of the Desiccated Lake System on Precipitation in the Basin of Mexico City
}

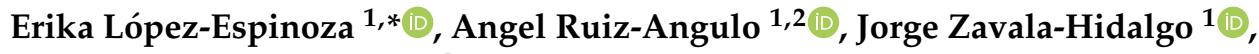 \\ Rosario Romero-Centeno ${ }^{1} \mathbb{D}$ and Josefina Escamilla-Salazar ${ }^{3}$ \\ 1 Centro de Ciencias de la Atmósfera, Universidad Nacional Autónoma de México, Mexico City 04510, Mexico; \\ angel@vedur.is (A.R.-A.); jzavala@atmosfera.unam.mx (J.Z.-H.); rosario@atmosfera.unam.mx (R.R.-C.) \\ 2 Icelandic Meteorological Office, Bústaðavegur 9, 105 Reykjavík, Iceland \\ 3 Facultad de Ingeniería, Universidad Nacional Autónoma de México, Mexico City 04510, Mexico; \\ josefinaeslzr@gmail.com \\ * Correspondence: danae@atmosfera.unam.mx; Tel.: +52-55-5622-4089
}

Received: 5 August 2019; Accepted: 12 October 2019; Published: 17 October 2019

\begin{abstract}
Mexico City constitutes one of the largest concentrations of population on the planet and is settled in a valley that, before the 16th century, had a lake system. The lakes were desiccated artificially, and currently, only small lakes remain. The impact of the lake system desiccation on precipitation was studied by performing numerical experiments: with the ancient lake system and without it. The experiments were carried out with the Weather Research and Forecasting (WRF) model coupled with a lake model for two months, using identical initial and boundary conditions, where only the system and lake physics were changed. The mean daily accumulated precipitation reduced when the system was removed. Additionally, the hourly distribution of rainfall changed from a relatively small diurnal variability when there was a lake system to a larger variability with a peak in the afternoon when the system was removed. Extreme precipitation events became more intense in the simulations with lakes. When the lakes were removed, the diurnal temperature range increased, and the boundary layer height became more variable, with a higher daily maximum. The results presented here show that the WRF-Lake model leads to opposite results compared to those with a non-coupled lake.
\end{abstract}

Keywords: WRF-Lake model; lake-atmosphere interaction; lake desiccation

\section{Introduction}

Lakes play an important role in regulating regional weather and climate. They have a small albedo and low surface roughness, as well as a high heat capacity and thermal conductance [1,2]. Thus, lake-atmosphere interactions modify regional water cycles and energy budgets. Additionally, lakes are larger sources of moisture for the lower atmosphere [1]. Compared to surrounding land surfaces, a lake tends to reduce the diurnal temperature range (DTR) [3,4]. A lake contributes significantly as a source of latent heat flow; its high heat capacity results in a lower temperature increase compared to that generated by soils since it redistributes energy within a thicker layer.

In Mexico City, the urbanization process causes extreme modifications in land cover and consequently significant changes in the surface energy balances [5]. It has been found that the impact of this process in the last 100 years resulted in an increase in surface air temperature of up to $2{ }^{\circ} \mathrm{C}[6-8]$, enhancing the urban heat island signature. Additionally, urbanization has also modified, even in a relatively short timescale, the hydrological cycle. References [9] and [10] showed changes of the precipitation patterns in Mexico City during 1941-1985 from observations and during 1993-2007 from numerical simulations. Those changes in precipitation patterns are a consequence of the increase 
in pollution (aerosols) and land use and land cover changes (LULCCs) within an already urbanized area. They showed a close relationship between the surface exchange processes in large urban areas and the modified behavior of precipitation. The numerical study [10] emphasizes the need for proper physics parameterizations when performing simulations with regional models. Particularly, studies have shown that inclusion of the lake's effect improves the performance of weather and climate models [1], and the errors of predicted variables like surface temperature, evaporation, thermal conditions, convection, and precipitation can be reduced mainly over the lake regions [1,4,11-13]. Studies in Lake Malawi, located in Southeast Africa, showed an increase in precipitation resulting from including the lake effect in their numerical simulation [14], suggesting that Lake Malawi was a source of water vapor that enhanced precipitation [15]. Simple 1-Dimension (1-D) lake models are commonly coupled with regional weather models [13]. The coupled lake model in the Weather Research and Forecasting (WRF) model (WRF-Lake) is a 1-D model that has been widely used to study how the lake impacts over regional weather $[1,4,12,16]$. Reference [11] analyzed the performance of the WRF-Lake model for Lake Tai and found that the model improved the predicted lake surface temperature (LST) compared to the WRF without a coupled lake model (uncoupled WRF), but also found that it presented significant bias. References [4] and [17] evaluated the WRF-Lake for the Great Lakes and Erhai Lake separately, and found improvements in LST but with significant bias. An evaluation of the thermal characteristics for different lake models (FLake, WRF-Lake, and CoLM-Lake) has been performed in [1]. They found that the three models with default parameters exhibited distinct errors in the simulated vertical temperature profile. For the best results, calibrated lake models have been employed $[1,4,13]$. Particularly, Reference [13] evaluated the performance of the WRF model in winter and summer seasons for events with and without precipitation through three experiments: uncoupled WRF, WRF-Lake with default parameters, and calibrated WRF-Lake. The evaluation was conducted for two freshwater lakes in China, Poyang Lake and Dongting Lake. For the winter precipitation case, the performance of the WRF-Lake was worse than that of the uncoupled WRF. Particularly, in Dongting Lake, they showed that all the three experiments had dry biases for summer precipitation; however, with the default and calibrated models, more precipitation was simulated. Additionally, the default and calibrated models significantly reduced surface temperature and dew-point temperature biases compared to the experiment with the uncoupled model. However, the calibrated model performed better than the default model. Particularly, Reference [18] analyzed the impact on precipitation due to the ancient lake system desiccation in the Valley of Mexico using the uncoupled WRF version, finding an increase in regional precipitation when the lake system was removed. It is worth mentioning that the WRF-Lake model was available in the particular used by [18].

In this context, the present study examines the changes in precipitation patterns due to the lake system desiccation using the WRF-Lake model. For the numerical experiments, the ancient water body, the depth, and the LST initialization were modified. The numerical experiments considered the current conditions of land cover and the scenario of a lake system representing conditions similar to those of the basin during the sixteenth century. An analysis of the differences between the simulations regarding the precipitation patterns is presented, including the importance of lake physics, air temperature, and the mixed layer height. Section 2 introduces the study area and explains the methods used for this work; the results are presented in Section 3, which are later discussed in Section 4, and finally the conclusions are presented in Section 5.

\section{Methods}

\subsection{Study Area}

The Valley of Mexico is located in the Center of Mexico in a tropical zone at $2240 \mathrm{~m}$ above the sea level and with complex orography. It is surrounded by mountain ranges to the east, west, and south (Figure 1) [19,20]. The valley is the most important industrial and economic region of the country, and it constitutes one of the largest concentrations of population on the planet. The existence of a lake 
system in the Basin of the Valley of Mexico motivated the establishment of human settlements [21,22]. During the 16th century, this lake system conformed an endorheic basin covering an area of around $1500 \mathrm{~km}^{2}$ with an average depth of $1.5 \mathrm{~m}$ (Figure 1b) [6,23,24]. Later, the lake system experienced several modifications and nowadays it is almost completely desiccated, remaining only around $1.3 \%$ of its original area (Figure 1a). The climate in the Valley of Mexico is influenced by tropical and mid-latitude meteorological systems, and it has suffered significant changes $[3,6,9,10,18,25-28]$ due to the ancient lake system desiccation $[3,6,18]$. At the present time, its climate is characterized by two well-defined seasons: the dry season, which spans from November to May, and the rainy season, which runs from June to October. The dry season can be subdivided into the following two subseasons: the dry-hot, from March to May, when dry air with tropical characteristics dominates; and the dry-cold, from November to February, which is affected by polar-type air masses with low moisture content. During the rainy season, tropical maritime air masses with high moisture content is dominant. The average annual rainfall (1960-2001) in the valley is about $670 \mathrm{~mm}$, with the highest values in the Sierra del Ajusco and Sierra Nevada, where values greater than $1000 \mathrm{~mm}$ are reached, and with the lowest values occurring in the central part, between 500 and $600 \mathrm{~mm}$. The average annual evaporation is $1640 \mathrm{~mm}$, being more intense in March to May and a minimum in December [29]. At the beginning of the 20th century, the main types of land cover were grasslands, shrubland, cropland, and uninhabited arid lands. Urban growth, and in general the land cover transformations in the Valley of Mexico, have modified the landscape [22].
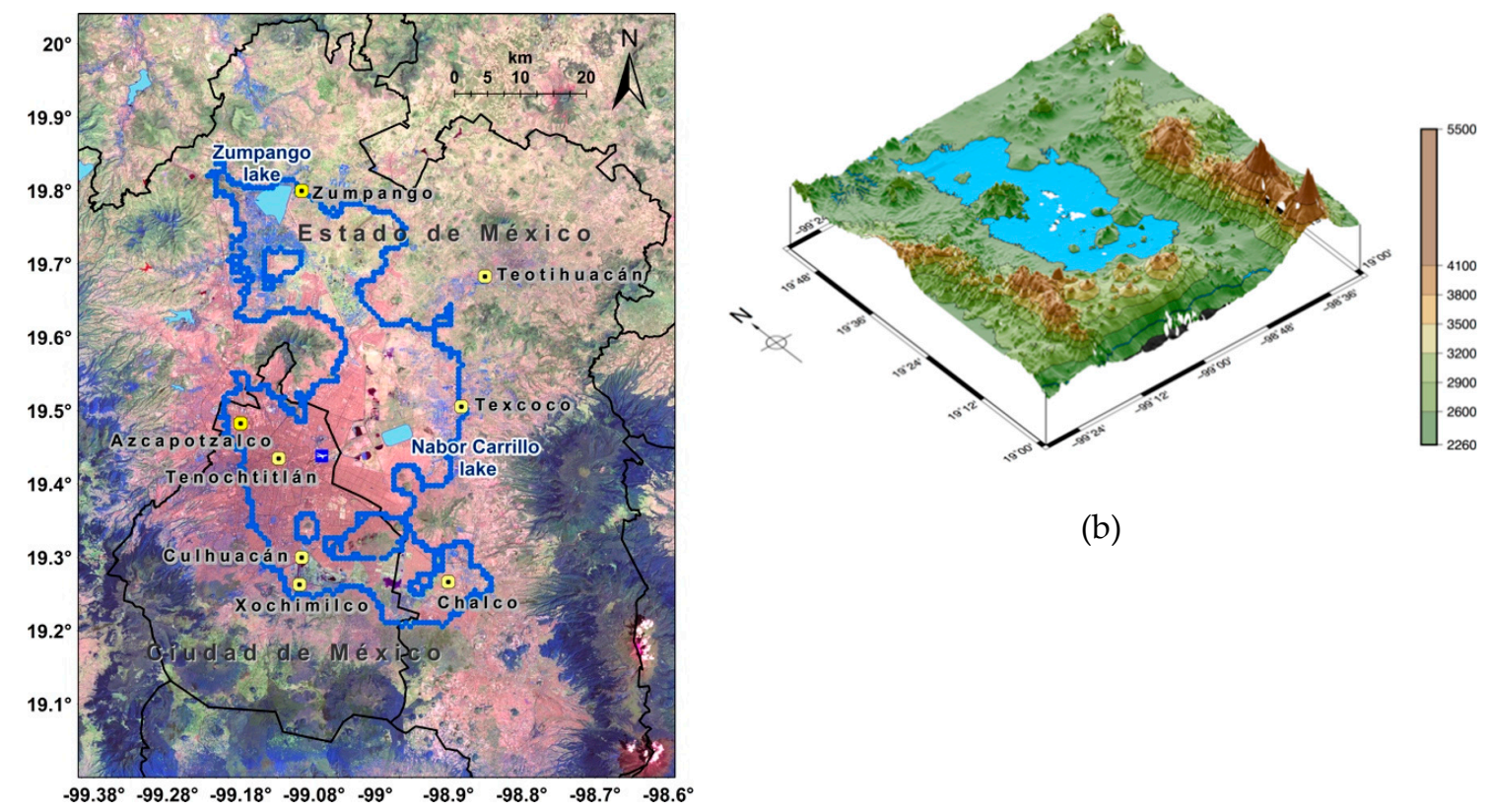

(b)

(a)

Figure 1. (a) LANDSAT image of the Valley of Mexico and the surrounding area. Black lines are the state borders and the blue line shows the limits of the area covered by an ancient lake (simulated). The corresponding sites used in the analysis are marked with yellow squares: Teotihuacan (TEO), Tenochtitlan (TEN), Texcoco (TEX), Xochimilco (XOC), Chalco (CHA), Culhuacán (CUL), and Zumpango (ZUM). (b) Digital elevation model of the valley with a representation of the area covered by the ancient lake [3]. Elevation is in meters according to the color bar.

\subsection{WRF Model Configuration}

For the Valley of Mexico, various efforts have been made to improve and evaluate the quality of the numerical weather prediction (NWP) based on the WRF model [28,30-33]. These evaluations have considered fundamental aspects, such as the quality of land cover data, initial and boundary conditions, 
spin-up time, horizontal resolution, and different land surface model (LSM) schemes. As a result of these evaluations, the quality of the regional NWP has improved, and it has also been concluded that the WRF model reproduces, in an acceptable manner, the general spatial and temporal patterns of meteorological systems. However, improving the NWP for the Valley of Mexico is a challenge that continues has to be investigated.

Considering the above, for our experiments, the WRF model was used with the Advanced Research WRF (ARW) dynamic solver version 3.6.1. Four numerical simulations were conducted: a simulation with current conditions of land cover (No-Lake), a simulation with the lake system that represents conditions similar to those of the basin during the 16th Century (Lake), both of them with an uncoupled WRF model (named NL/WRFu and L/WRFu, respectively), and the other two simulations were performed with the same conditions of No-Lake/Lake but with a coupled WRF or WRF-Lake model (named NL/WRFc and L/WRFc, respectively). These simulations were performed over two domains: an outer domain, which covers all of Mexico with a $20 \mathrm{~km}$ horizontal resolution, and a nested domain that includes the Valley of Mexico and the surrounding areas, with a horizontal resolution of approximately $6.7 \mathrm{~km}$ (Figure 2). Simulations were carried out for $120 \mathrm{~h}$ in forecast mode, with hourly outputs for a dry month (January) and for a representative month of the rainy season (August). The year 2012 was chosen for the simulations because there were no extreme events that could have caused heavy precipitation in the Valley of Mexico and was a year that presented neutral conditions of the ENSO phenomenon. During the month of January, sea surface temperature (SST) anomalies were below average in the tropical Pacific Ocean, showing conditions of a weak La Niña. Subsequently, the return to ENSO neutral conditions that persisted during the month of August was favored. Seven frontal systems occurred in January, of which six caused rainfall along the coast of the Gulf of Mexico. For the entire country, the average rainfall in January was $18.6 \mathrm{~mm}, 26 \%$ below average. In general, temperature fluctuations remained within the normal ranges of climate variability. For the whole country, the daily rainfall in August fluctuated between 2 and $15.4 \mathrm{~mm}$. From day 6 to day 14 of this month, the greatest contribution of moisture was observed, favored by the track of Hurricane Ernesto which caused significant rainfall outside the Valley of Mexico (the maximum value reported was $353.0 \mathrm{~mm}$ in Lerdo de Tejada, Veracruz) [34].

The WRF model configuration was based on that used in the operational forecasting system implemented at the Atmospheric Sciences Center of the National Autonomous University of Mexico (UNAM) [35]. A Mercator projection, a time-step of $120 \mathrm{~s}, 30$ terrain-following sigma levels in the vertical, and one-way nesting [36] were used. The initial and boundary conditions were taken from the Global Forecast System (GFS) model, and 0000 UTC data were used every six hours with a one-degree spatial resolution. Schemes used in the model physics were as follows: the Kain-Fritsch [37] for the cumulus parameterization, which was turned on for the two domains; the Rapid Radiative Transfer Model (RRTM) for the long wave radiation; the Dudhia for the shortwave radiation; and the Yonsei University (YSU) scheme for the planetary boundary layer (PBL) [38]. A previous regional study in the same area has shown the differences between schemes and concluded that the YSU PBL was the best choice for the MCMA-2006/MILAGRO field campaign in the Valley of Mexico [39]. The community Noah land surface model (Noah LSM), developed jointly by the National Centers for Environmental Prediction (NCEP) and National Center for Atmospheric Research (NCAR), was used for the land-surface processes [40]. This is a 4-layer soil temperature and moisture model, with canopy moisture and snow cover prediction. The soil layer depths are 10, 30, 60, and $100 \mathrm{~cm}$ from the surface. It includes the root zone, evapotranspiration, soil drainage, and runoff, taking into account vegetation categories, monthly vegetation fraction, and soil texture [38]. The land use and land cover database produced by the United States Geological Survey (USGS) was used, with 24 classes [41] and a class for the lake system configured. The Community Land Model (CLM) version 4.5, which is a one-dimensional scheme of energy and water balance, was used [42]. Particularly, it is worth mentioning that the WRF version 3.6.1 allows for proper nesting including this lake physics scheme. This scheme has been previously validated against observations and has eliminated a great deal of the 
numerical biases for precipitation, temperature, and heat fluxes $[43,44]$. The LST initialization for the Lake/WRFu simulation was estimated by spatial interpolation of the SST field from the GFS model [16], and the Lake/WRFc simulation was done using the daily-average surface air temperature field [38]. The first method, typically employed prior to the 2013 WRF version, can result in unrealistic lake temperatures and lead to results such as those reported by [18]. Reference [16] includes an extensive review of the evolution of the lake modules for WRF and it poses the positive and negative aspects of the solutions that have been commonly used. Finally, for both simulations, the total area of the lake system was $1689 \mathrm{~km}^{2}$, but only the Lake/WRFc simulation has a uniform depth of $2 \mathrm{~m}$ throughout the entire area $[20,23,45]$.

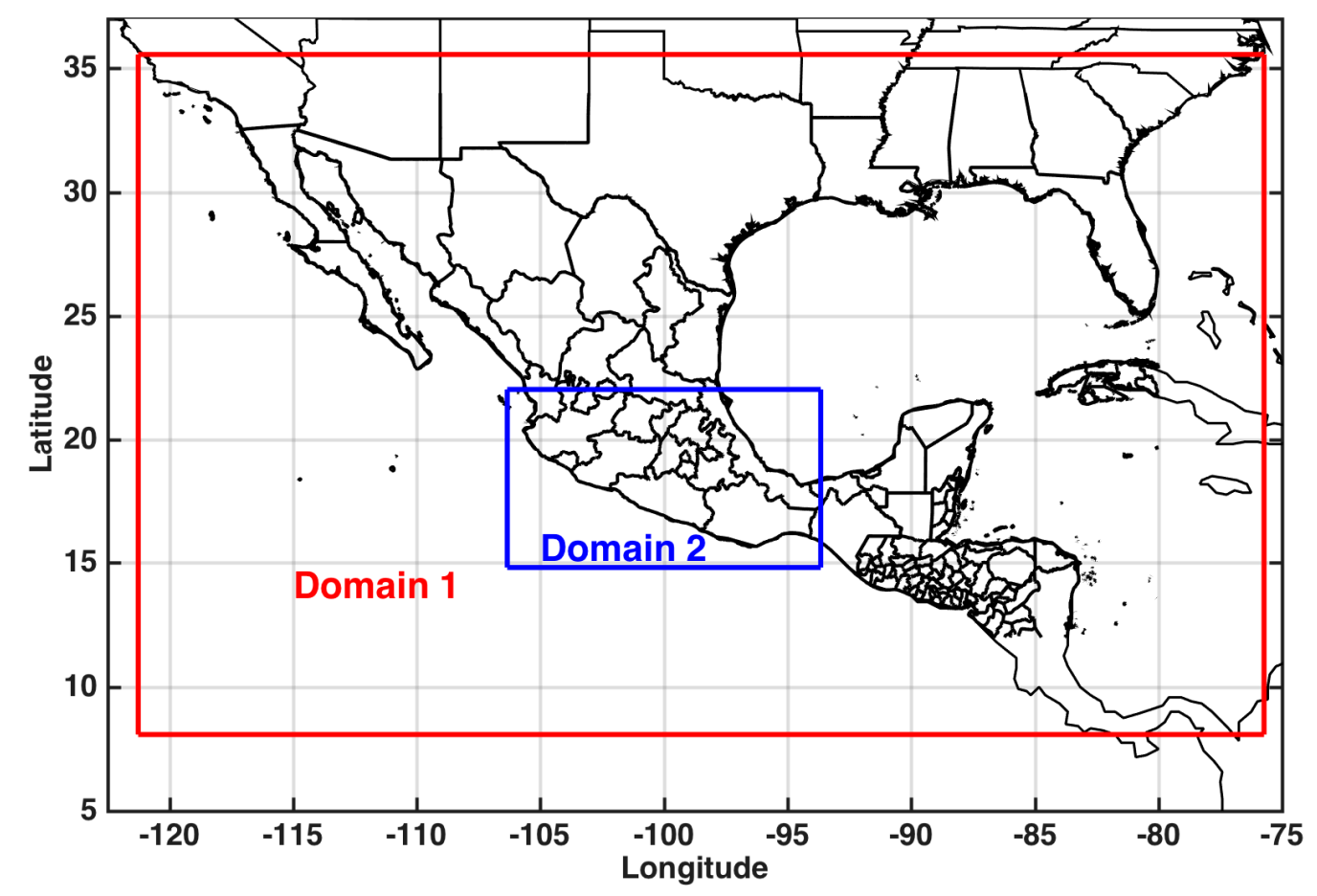

Figure 2. Domain of the simulations. The outer domain or Domain 1 (red) has a $20 \mathrm{~km}$ horizontal resolution and the nested domain or Domain 2 (blue) has a $6.7 \mathrm{~km}$ horizontal resolution.

\section{Results}

\subsection{Precipitation}

Figure 3 presents the spatial distribution of the monthly accumulated precipitation for August, the month with the largest change, for the four experiments. The aim of Figure 3 is to show the differences from including or not the effect of the lake system, comparing the simulation using the WRF-Lake model with those with the uncoupled WRF. The upper panels show the results from the simulations with a lake (L/WRFu; Figure 3a) and without a lake (NL/WRFu; Figure $3 b)$ using the uncoupled WRF model. Their difference (results obtained by NL/WRFu minus results obtained by $\mathrm{L} / \mathrm{WRFu}$ ) is shown in Figure 3c. For these experiments, the difference shows an increase in monthly accumulated precipitation when the lake system is removed. Similar results were obtained by [18]. The lower panels in Figure 3 show the monthly accumulated precipitation resulting from the simulations for the same month using the WRF-Lake model. Compared with the difference between the previous simulations with $\mathrm{L} / \mathrm{WRFu}$ and NL/WRFu, the difference between results obtained with NL/WRFc and results obtained with L/WRFc (Figure 3f) shows a reduction of the total precipitation due to the desiccation of the lake system. From this result, it is observed that the lake-atmosphere interaction plays an important role in this system. The precipitation enhancement is larger over the lake and towards the south of the basin surrounded by steep mountains. 


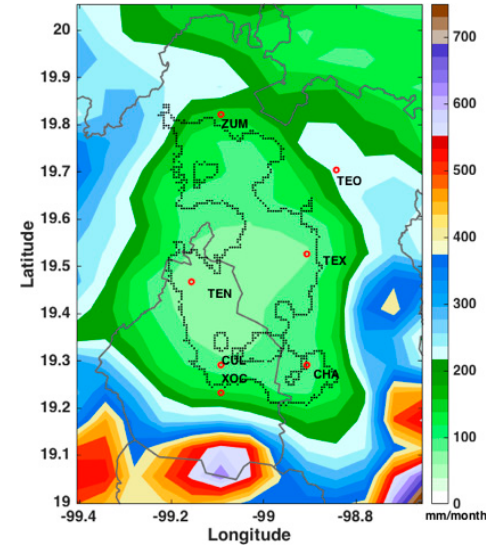

(a)

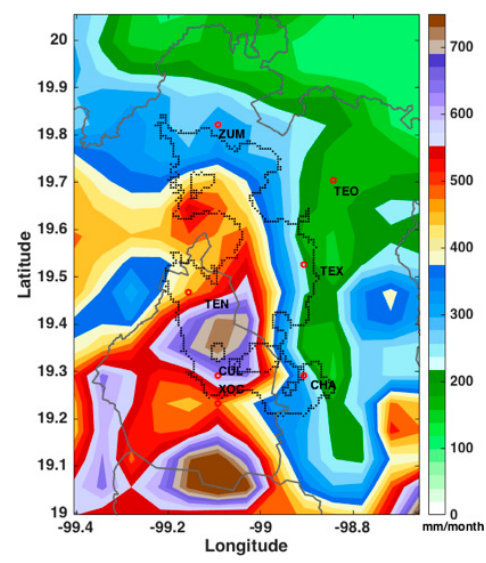

(d)

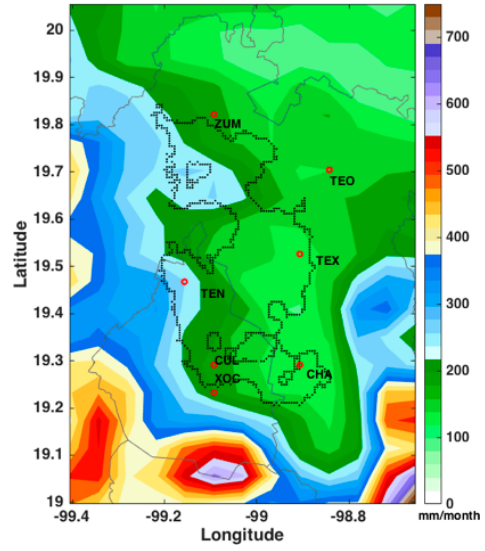

(b)

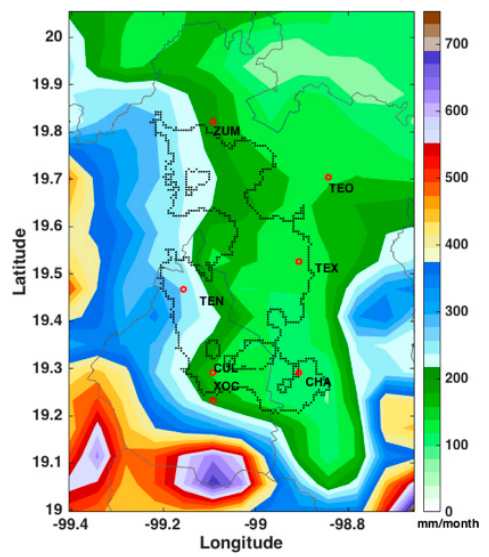

(e)

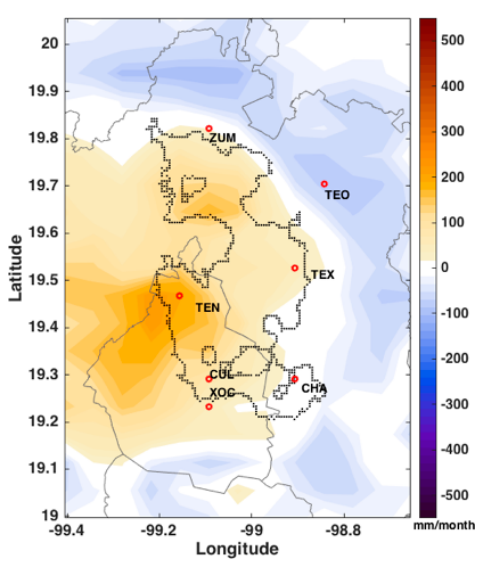

(c)

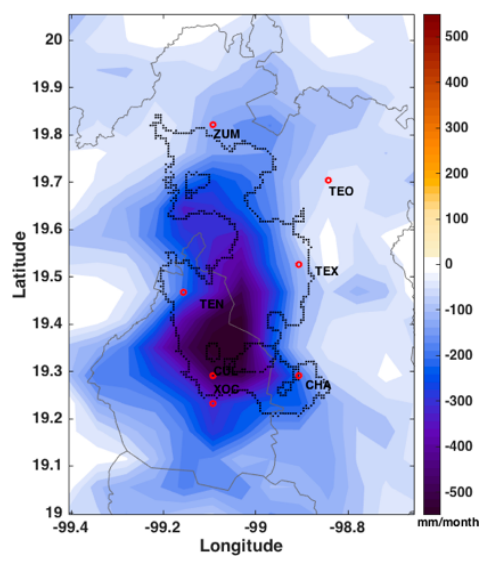

(f)

Figure 3. Upper panels: accumulated precipitation for August showing the simulations with L/WRFu (a) and NL/WRFu (b), both using the uncoupled WRF model, and the difference of results obtained with NL/WRFu and L/WRFu (calculated by results obtained with NL/WRFu minus results obtained with $\mathrm{L} / \mathrm{WRFu}$ ) (c). Lower panels: accumulated precipitation for August showing the simulations with L/WRFc (d) and NL/WRFc (e), both using the WRF-Lake model, and the difference of results obtained with L/WRFc and NL/WRFc (calculated by results obtained with NL/WRFc minus results obtained with $\mathrm{L} / \mathrm{WRF}$ ) (f).

We attribute the difference in precipitation shown in Figure $3 c, f$ to the poor representation of the lake system in the uncoupled WRF model, which considers a shallow water surface that inhibits the interaction between the lake and the atmosphere due to the lack of inclusion of the lake's physics. In addition to the change in precipitation, modifications in the net radiation can be observed. Figure 4 shows the latent and sensible heat fluxes for both simulations with lake, L/WRFu and L/WRFc. Although the water bodies in both simulations are sources of moisture, the proportion of energy that is associated with the latent heat flux is very different (see Figure $4 a, c)$, partially due to the heat capacity of the water bodies, which is greater in the system with a prescribed depth. Thus, more heat is needed to increase the temperature of the lake that has a given depth because there is more water and more thermal energy has been absorbed, which favors the evaporation of the water contained in the system itself. The heat capacity has been then modified in both simulations and the resulting sensible heat flux shows significant differences, as can be seen in Figure $4 \mathrm{~b}, \mathrm{~d}$. 


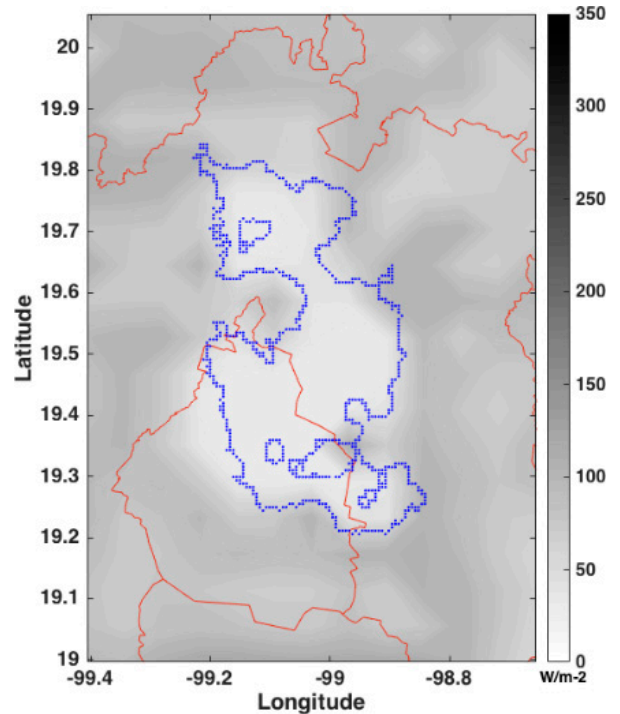

(a)

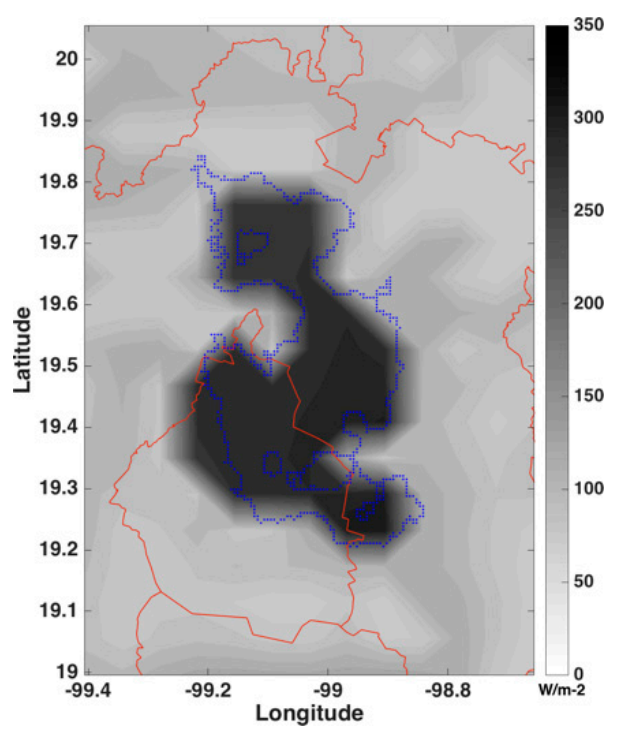

(c)

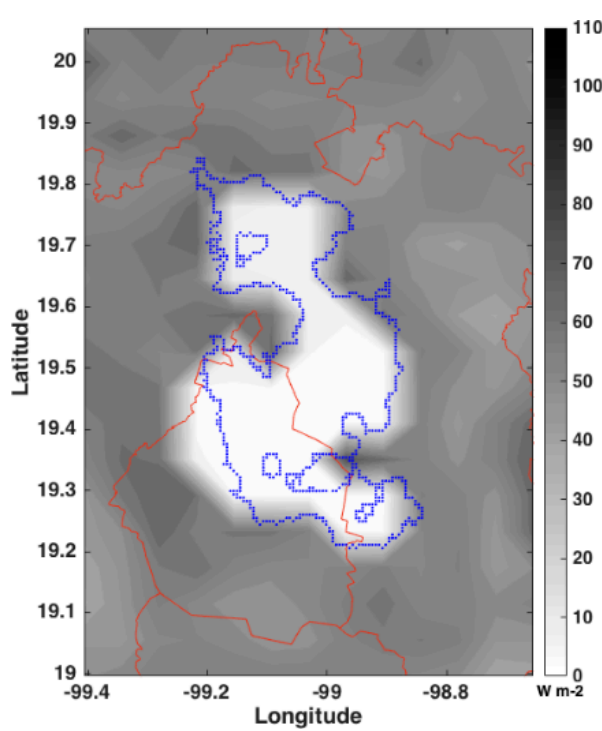

(b)

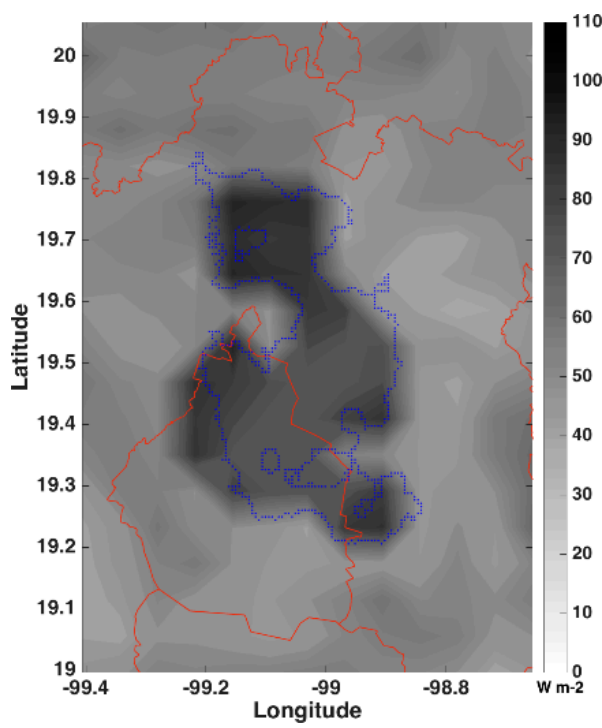

(d)

Figure 4. Mean monthly heat fluxes for the simulations with a lake system: latent (a) and sensible (b) heat fluxes for L/WRFu; latent (c) and sensible (d) heat fluxes for L/WRFc.

Additionally, a significant change can be observed in the winds. Figure 5 shows the difference of the average wind speed between No-Lake and Lake simulations for the uncoupled WRF (Figure 5a) and coupled WRF models (Figure 5b), and a snapshot of the wind vectors representing the changes in magnitude and direction for both WRFu and WRFc (Figure 5c,d, respectively). The lake system with the coupled WRF model (Figure 5b) increases, in general, the magnitude of the winds and modifies the regional circulation, which is dominated by a convergence zone that moves from the south to the central part of the lake system. Figure $5 \mathrm{~d}$ shows this convergence zone in the central part of the lake system. 


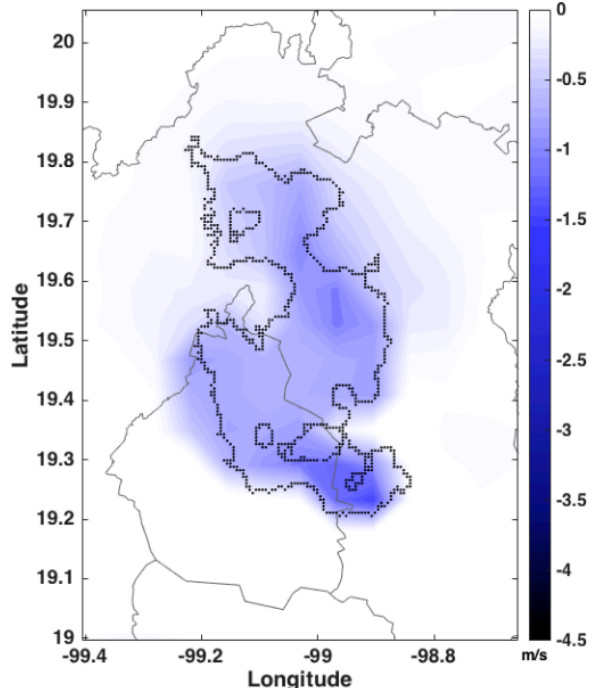

(a)

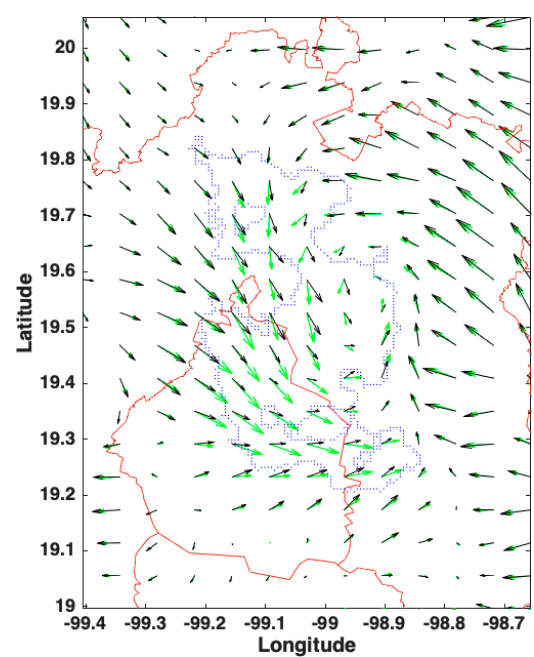

(c)

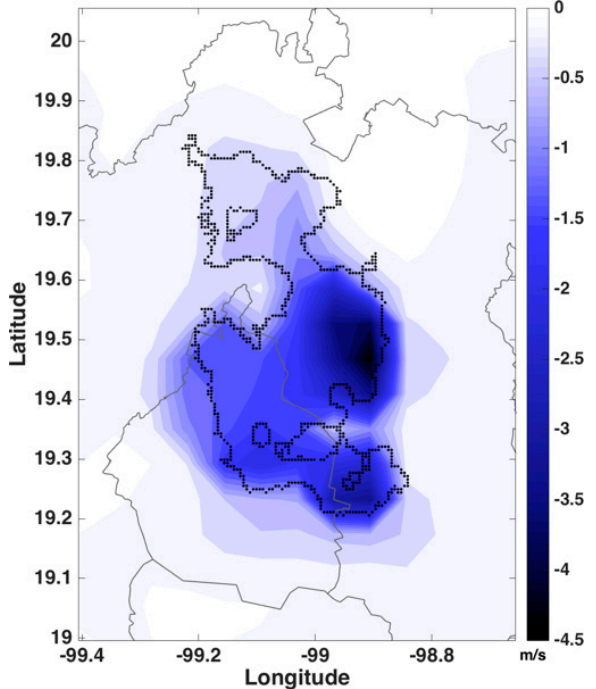

(b)

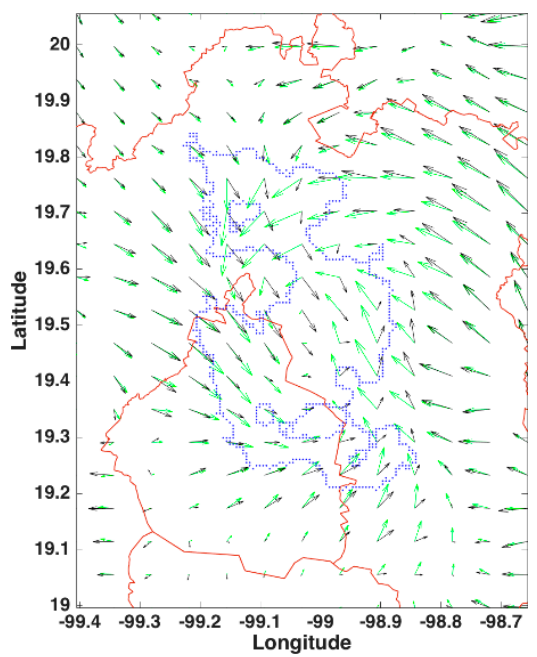

(d)

Figure 5. Difference between No-Lake and Lake simulations results of the wind speed at $2 \mathrm{~m}$ above the water surface with the uncoupled WRF (a) and the coupled WRF (b) models. Wind directions obtained with No-Lake (black arrows) and Lake (green arrows) simulations using the uncoupled WRF (c) and coupled WRF (d) models. The time in both simulations is 3:00 UTC.

Considering the above, the following two simulations were implemented using the WRF-Lake model: the control experiment with current conditions $(\mathrm{NL} / \mathrm{WRFc})$ and the experiment including the lake system (L/WRFc).

The mean hourly precipitations for the dry (January) and wet (August) months were computed for sites located within and outside the ancient lake system (see Figure 1 for the location of the sites). The sites were chosen not only to quantify the effect that this numerical experiment has on its surroundings, but also to represent the major pre-Columbian city-states of the Valley of Mexico. In general, precipitation in the L/WRFc experiment occurs mainly during the late evening and night hours (GMT-6), while in the NL/WRFc experiment it occurs earlier in the evening. Figure 6 shows the mean hourly precipitations for two sites in January and August. The Tenochtitlán (TEN) station was chosen as an example of the sites within the ancient lake and Xochimilco (XOC) for those just outside of it. The mean daily precipitations in both months were larger in the experiments with lakes $(\mathrm{L} / \mathrm{WRF})$ 
for all of the analyzed sites. The mean daily precipitations for all the stations shown in Figure 1 are summarized in Table 1. For the L/WRFc experiment, a delay of approximately one hour is observed in the occurrence of the maximum rainfall relative to the NL/WRFc simulation results, as shown in Figure 6. In addition, the $\mathrm{L} / \mathrm{WRF}$ simulation shows an increase in precipitation that is noticeable during the first hours of the day for both January and August.

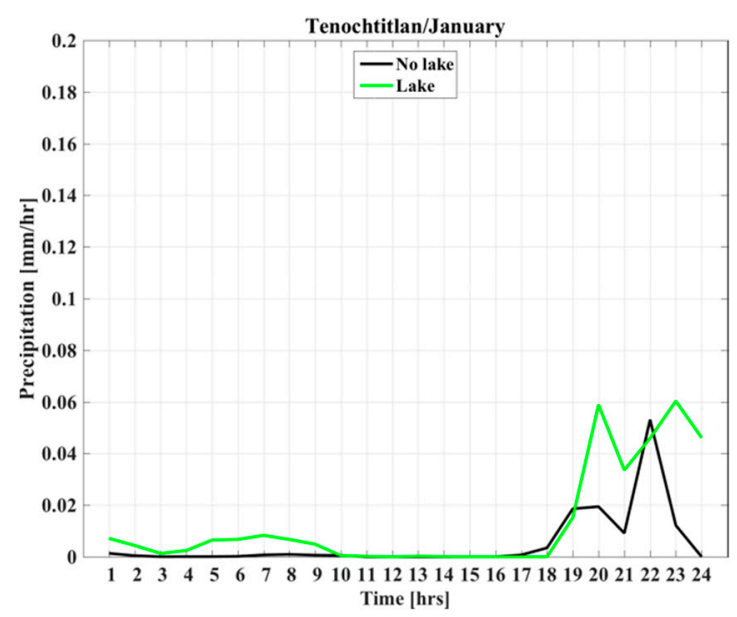

(a)

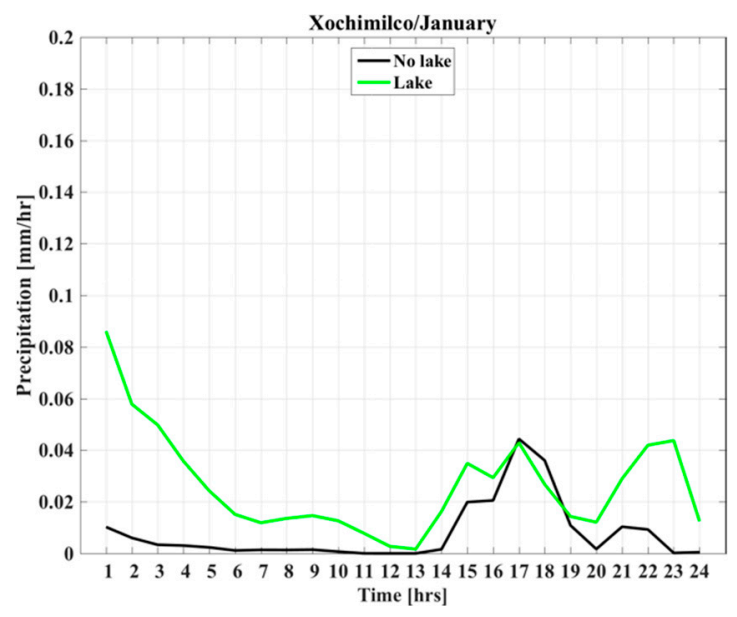

(c)

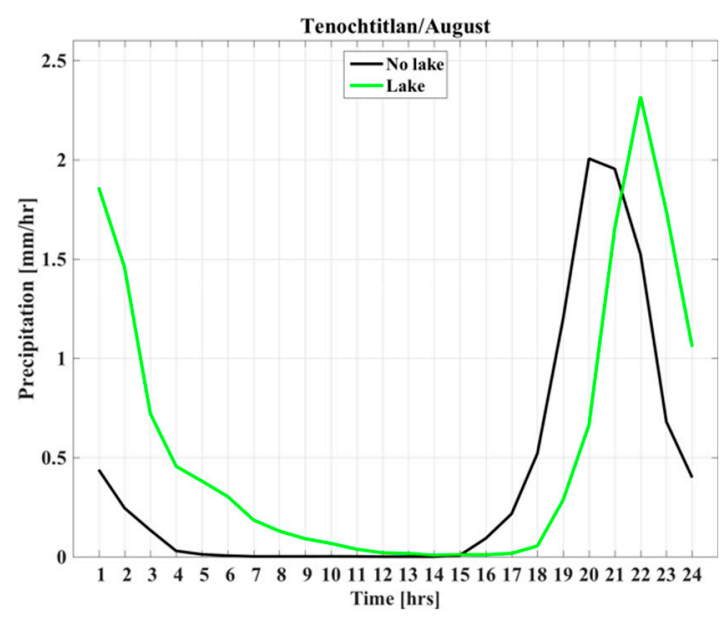

(b)

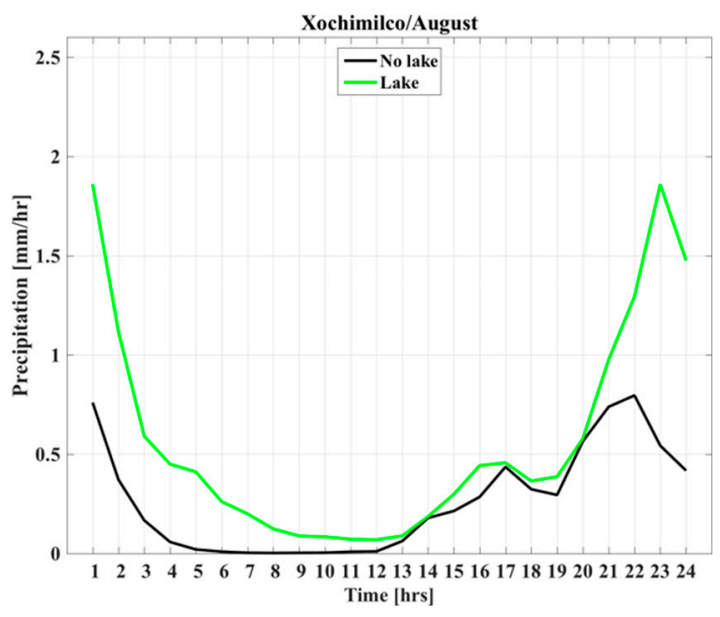

(d)

Figure 6. Mean hourly precipitation for: Tenochtitlán in January (a) and August (b), and Xochimilco in January (c) and August (d). (No-Lake: NL/WRFc and Lake: L/WRF.) 
Table 1. Mean hourly precipitations and mean daily accumulated precipitations for January and August for all of the analyzed sites (see Figure 1 for the location of the sites): Teotihuacan (TEO), Tenochtitlan (TEN), Texcoco (TEX), Xochimilco (XOC), Chalco (CHA), Culhuacán (CUL), and Zumpango (ZUM). All experiments used the WRF-Lake model.

\begin{tabular}{cccccccccc}
\hline Analyzed Sites & \multicolumn{4}{c}{ January } & \multicolumn{2}{c}{ No-Lake } & \multicolumn{2}{c}{ Lake } \\
\hline & \multicolumn{2}{c}{ No-Lake } & \multicolumn{2}{c}{ Lake } & \multicolumn{2}{c}{ August } \\
& $\begin{array}{c}\text { Daily } \\
\mathbf{m m} / \mathbf{h}\end{array}$ & $\begin{array}{c}\text { Accum. } \\
\mathbf{m m} / \text { day }\end{array}$ & $\begin{array}{c}\text { Daily } \\
\mathbf{m m} / \mathbf{h}\end{array}$ & $\begin{array}{c}\text { Accum. } \\
\mathbf{m m} / \mathbf{d a y}\end{array}$ & $\begin{array}{c}\text { Daily } \\
\mathbf{m m} / \mathbf{h}\end{array}$ & $\begin{array}{c}\text { Accum. } \\
\mathbf{m m} / \text { day }\end{array}$ & $\begin{array}{c}\text { Daily } \\
\mathbf{m m} / \mathbf{h}\end{array}$ & $\begin{array}{c}\text { Accum. } \\
\mathbf{m m} / \text { day }\end{array}$ \\
\hline TEN & 0.01 & 0.12 & 0.01 & 0.31 & 0.39 & 9.47 & 0.56 & 13.54 \\
\hline TEO & 0 & 0.08 & 0 & 0.07 & 0.17 & 4.02 & 0.31 & 7.38 \\
\hline TEX & 0 & 0.01 & 0.01 & 0.33 & 0.16 & 3.86 & 0.25 & 5.91 \\
\hline XOC & 0.01 & 0.19 & 0.03 & 0.64 & 0.26 & 6.26 & 0.57 & 13.73 \\
\hline CHA & 0 & 0.03 & 0.01 & 0.34 & 0.13 & 3.07 & 0.27 & 6.39 \\
\hline CUL & 0 & 0.08 & 0.03 & 0.64 & 0.23 & 5.41 & 0.57 & 13.66 \\
\hline ZUM & 0.01 & 0.19 & 0.01 & 0.33 & 0.31 & 7.30 & 0.35 & 8.44 \\
\hline Average & 0 & 0.10 & 0.02 & 0.38 & 0.23 & 5.63 & 0.41 & 9.87 \\
\hline
\end{tabular}

\subsection{Air Temperature}

The air temperature at $2 \mathrm{~m}$ above the surface was used to investigate the effect of the ancient lake system on the thermal conditions in the region. The differences of air temperature at $2 \mathrm{~m}$ above the surface between both simulations are also remarkable. These differences are observed in the amplitude of the diurnal cycle and in a temporal shift in the occurrence of the maximum and minimum temperatures, with cooler nights and warmer days when the lake is removed. For example, at Tenochtitlán (TEN), the differences on the diurnal cycle in both months reach about $4{ }^{\circ} \mathrm{C}$ for the minimum temperature and about $3^{\circ} \mathrm{C}$ for the maximum temperature (Figure 7 ). Outside of the lake system, the differences are relatively smaller but follow the same pattern, as can be observed for Xochimilco (XOC) (Figure 7). Additionally, in Tenochtitlán, the maximum and minimum temperatures are reached approximately two hours before when the lake is removed.

To study the changes in the maximum (Tmax) and minimum (Tmin) diurnal temperatures, we looked at the DTR, which is defined as: DTR = Tmax - Tmin. The differences in DTR between the NL/WRFc and L/WRFc experiments are shown in Figure 8 for January and August. It can be observed in both dry and wet conditions that the DTR is always greater when the lake is removed, that is, in the current conditions of land cover. Additionally, it is possible to appreciate that the DTR gradient is influenced by the mountains to the southwest as the contours are closer to each other, whereas it is smoother in the north and northeast where the topography is rather flat. 


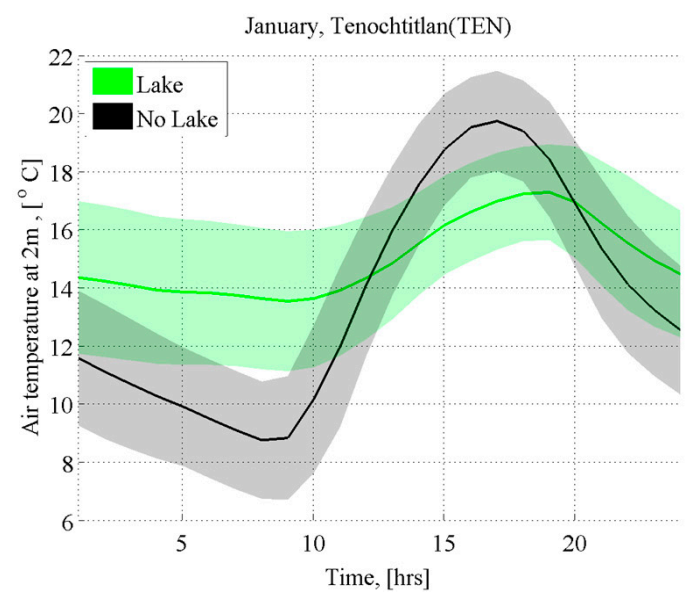

(a)

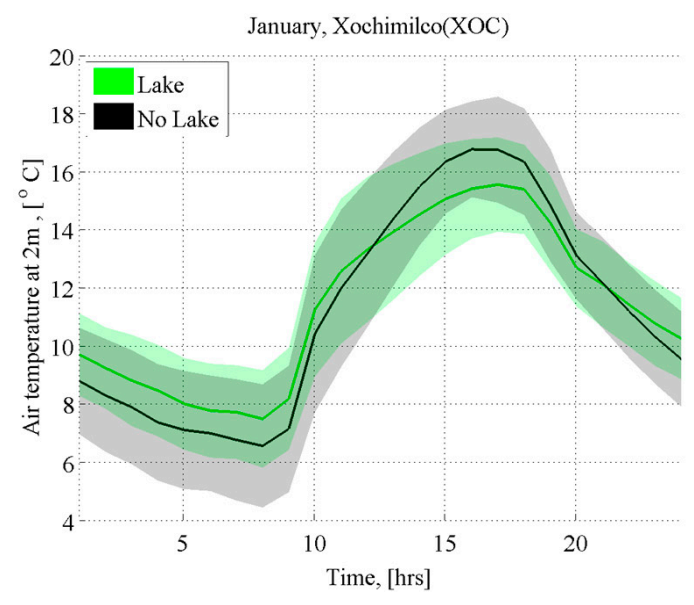

(c)

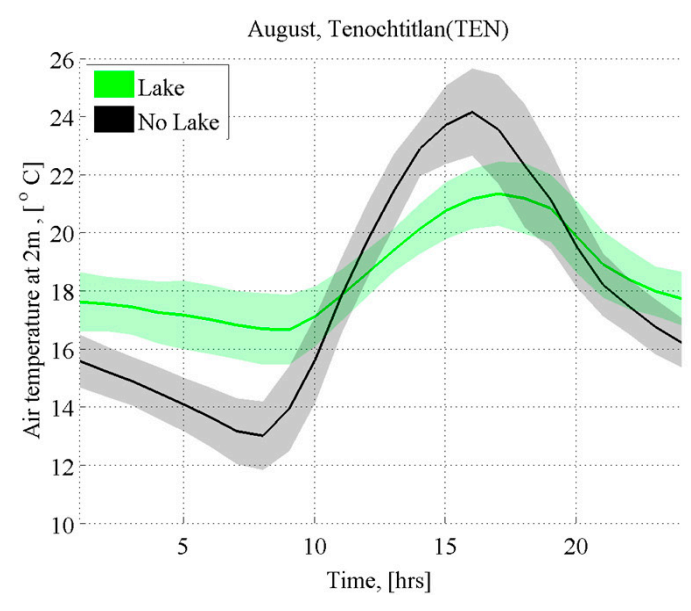

(b)

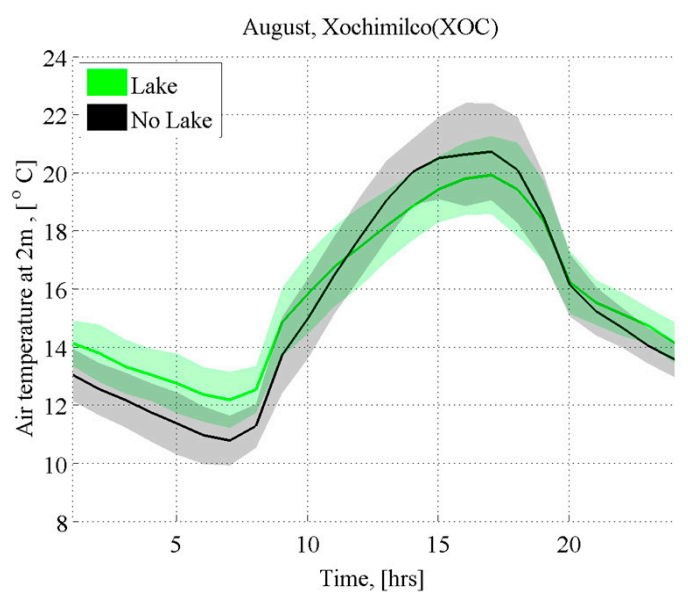

(d)

Figure 7. Mean hourly air temperature at $2 \mathrm{~m}$ above the surface at Tenochtitlán in January (a) and August (b), and at Xochimilco in January (c) and August (d). Green colors correspond to the L/WRFc simulation and black-gray colors correspond to the NL/WRFc simulation. The solid lines correspond to the mean monthly values of the hourly temperature data and the bands represent the associated variability for the particular month and station. (No-Lake: NL/WRFc; Lake: L/WRFc.) 


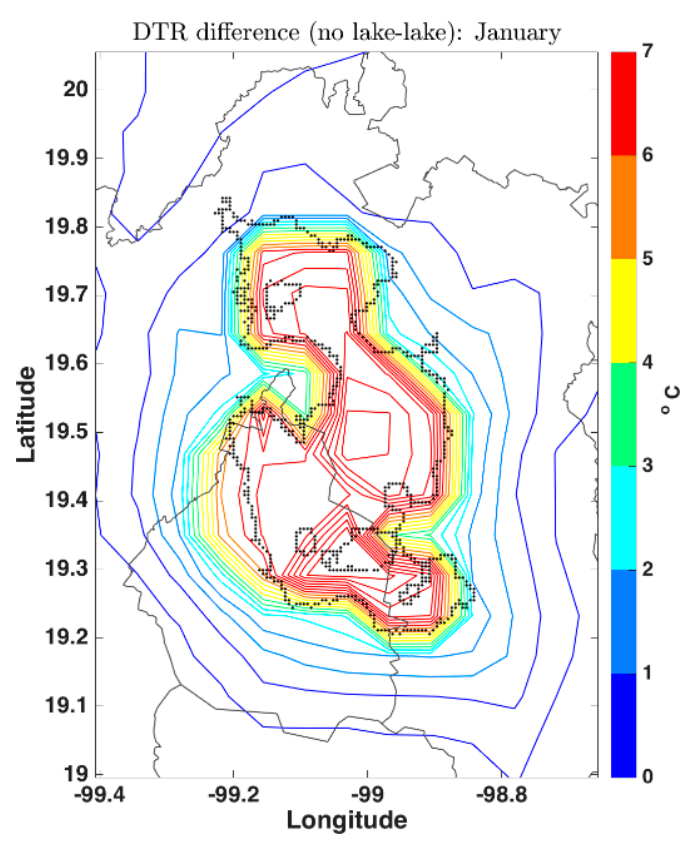

(a)

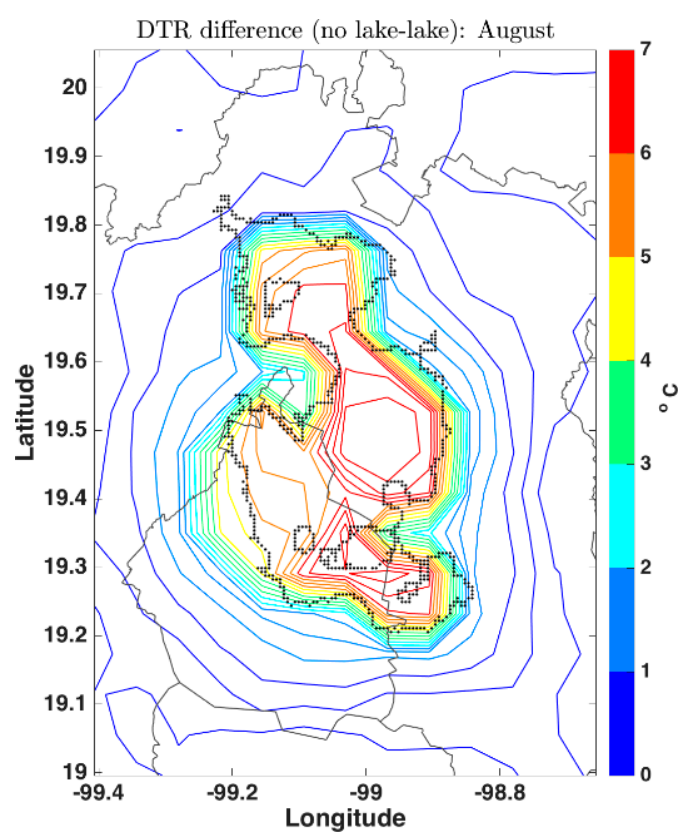

(b)

Figure 8. Mean diurnal temperature range (DTR) difference between the NL/WRFc and L/WRFc simulations in January (a) and August (b).

\subsection{Planetary Boundary Layer Height (PBLH)}

The modification of the surface energy fluxes due to the desiccation of the lake system results in a significant change in the PBLH. The area that was covered by the lake shows a fairly homogeneous PBLH, between 100 and $500 \mathrm{~m}$ during the whole day, with a small peak in the afternoon. There is a delay in the occurrence of this peak related to the proximity to the lake; the closer the proximity to the lake, the later the peak occurs. For example, Figure 9 shows the hourly average of PBLH for the two selected sites (TEN and XOC), where this delay is observed. The shift of the maximum PBLH is associated with the balance of surface energy fluxes at each location. In the case of the NL/WRFc experiment, the maximum PBLH ranges are, on average, between 1200 and $1800 \mathrm{~m}$ in January and between 1300 and $2100 \mathrm{~m}$ in August. Additionally, compared to results obtained with the L/WRFc experiment, the PBLH during the night decreases significantly.

The patterns described above, for temperature and PBLH, intensify within the area covered by the ancient lake and gradually decrease towards areas that were not covered by water. Consistent with the DTR spatial distribution, the influence of the lake is slightly larger in the southern basin, as can be observed in the difference of maps for the DTR and PBLH (Figures 8 and 10, respectively). 


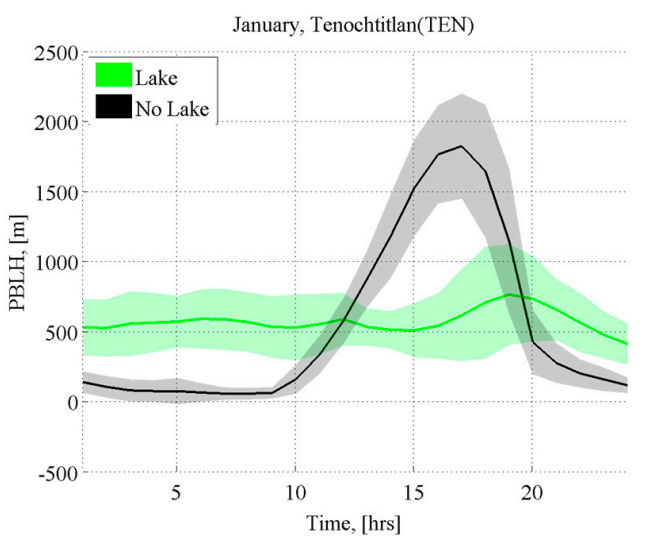

(a)

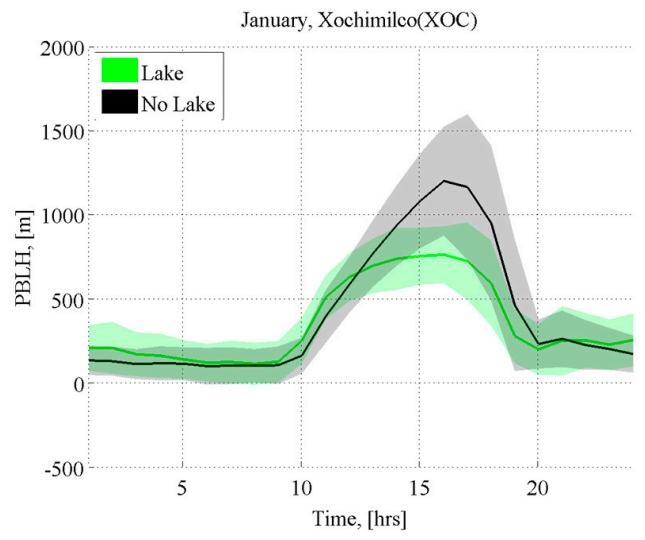

(c)

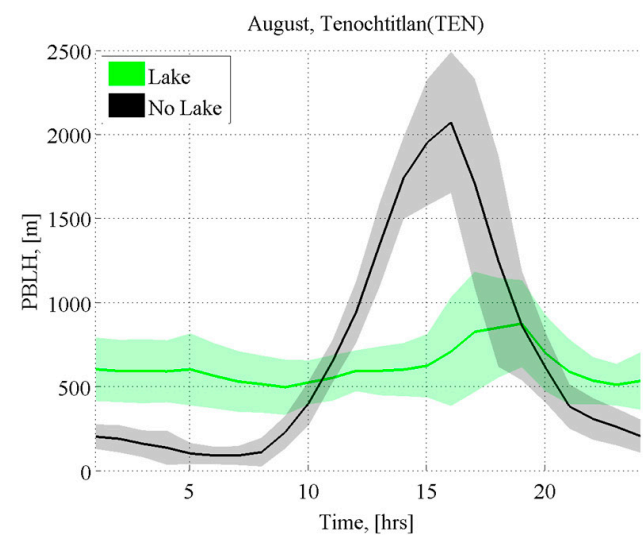

(b)

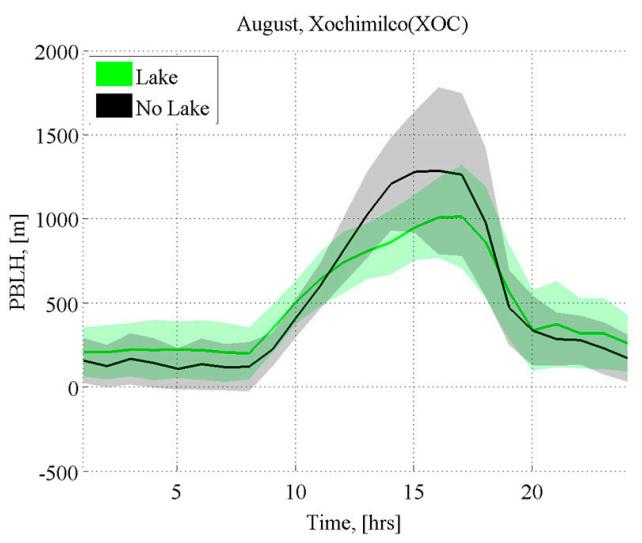

(d)

Figure 9. Hourly means of the planetary boundary layer height (PBLH) at Tenochtitlan in January (a) and August (b), and at Xochimilco in January (c) and August (d). Green colors correspond to the L/WRFc simulation and black-gray colors correspond to the NL/WRFc simulation. The solid lines correspond to the mean monthly values of the hourly PBLH data and the bands represent the associated variability for the particular month and station. (No-Lake: NL/WRFc; Lake: L/WRFc.)

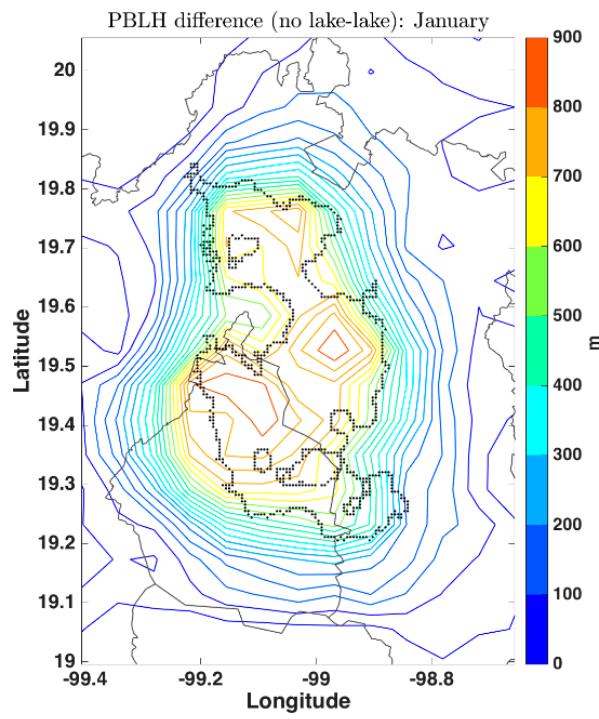

(a)

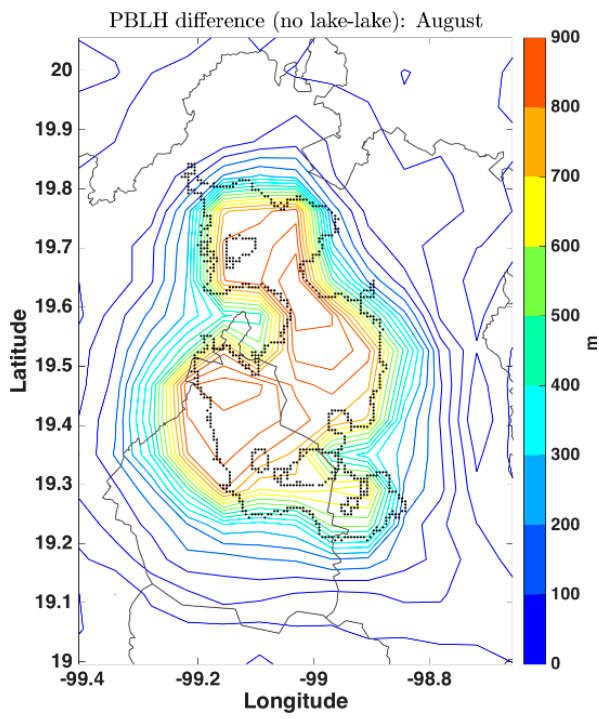

(b)

Figure 10. Difference of mean maximum PBLHs between the NL/WRFc and L/WRFc simulations in January (a) and August (b). 


\section{Discussion}

An analysis of the effects associated with the desiccation of the ancient lake system in the Mexico City Basin was carried out by implementing the WRF numerical model in this region.

The latest versions of the WRF, after version 3.6, have a simple module with lake physics available [16,42]. Surprisingly, adding a more realistic lake with depth and its basics physics (WRF-Lake), instead of a shallow lake without physics, to the simulations produces a breaking point in terms of the conclusions that can be obtained. We found that deactivating this module coupled with the WRF results in a decrease in precipitation in the Mexico City Basin as a consequence of desiccating the lake system. In Figure 3, specifically for precipitation, it is shown that implementing a lake in the WRF does not have the same result as including the coupled lake model. Even if the lake physics in the WRF module is simple, flux exchanges are more realistic $[43,44]$. The consequence of this binary process of lake and no-lake numerical experiments results in less precipitation in the valley with the current conditions compared to the past conditions (Figure 3d-e), which contradicts studies like [18] where the lake physics is not involved and a shallow lake is simulated. Thus, the results presented in Figure 3 demonstrate that those discrepancies are a consequence of not including the basic physics of the lake system, which leads to opposite results in terms of the amount of precipitation. Regardless of our resolution and different years of simulations, we are able to recover and increase in precipitation if the lake physics are turned off.

Using WRF-Lake, the comparison between the control experiment (NL/WRFc) and the one that considers the ancient lake system (L/WRFc) shows differences in the behavior of several meteorological variables. Without the lake $(\mathrm{NL} / \mathrm{WRF})$, the average precipitation decreases and re-distributes along the day, and the DTR and mixed layer height become larger. The mixed layer height shows more diurnal variability, being deeper during day hours. These conditions favor convection in the afternoon and inhibit it during the night; therefore, rain conditions are more favorable when temperature is decreasing sharply in the afternoon (Figure 6). The reduction of the mixed layer height and the temperature decrease at night reduces the precipitation over that period.

The distributions of the hourly precipitation data are analyzed using box plots. The corresponding box plots for Tenochtitlán during August (Figure 11a) show very similar distributions for both simulations, including the intensity and number of heavy precipitation events. Hypothesis testing for the difference of means shows that there is not a statistically significant difference between them, even at a $10 \%$ significance level. On the other hand, the box plots of the hourly precipitation data for Xochimilco during August (Figure 11b) show that there are substantially more and stronger heavy precipitation events in the simulation with a lake $(\mathrm{L} / \mathrm{WRFc})$. In this case, the mean hourly precipitation is $0.52 \mathrm{~mm} / \mathrm{h}$, compared to $0.19 \mathrm{~mm} / \mathrm{h}$ for the simulation without a lake (NL/WRFc). The difference of means is statistically significant with a $p$-value of $<0.0001$. All the selected stations (see Table 1) showed a decrease in precipitation due to the lake desiccation. It can be observed that, to the southwest of the valley, the changes in precipitation are the largest, as shown in stations Xochimilco and Culhuacán (Figure 3f). On average, the mean daily accumulated precipitation for the month of August is $9.87 \mathrm{~mm} /$ day with a lake compared to $5.63 \mathrm{~mm} /$ day without a lake. The DTR shows differences between the two simulations, for both January and August, up to $7^{\circ} \mathrm{C}$. These differences have local maxima in the center and southeast of the lake and gradually decreases outward, as shown in Figure 8. The PBLH differences between the simulations are up to $900 \mathrm{~m}$, with a local maximum at the center of the lake in January and August (Figure 10). 


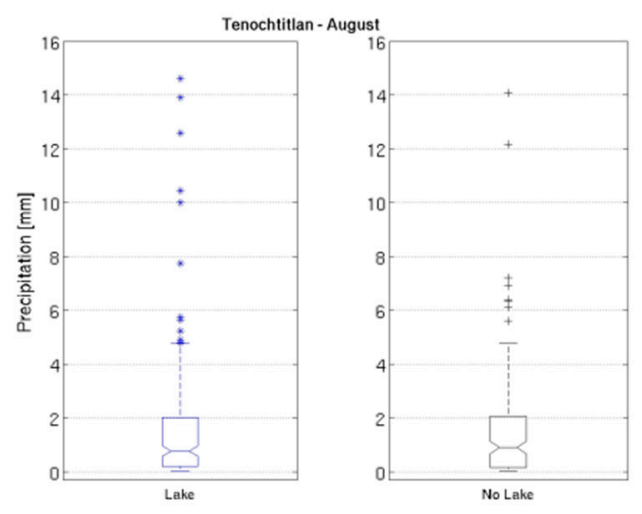

(a)

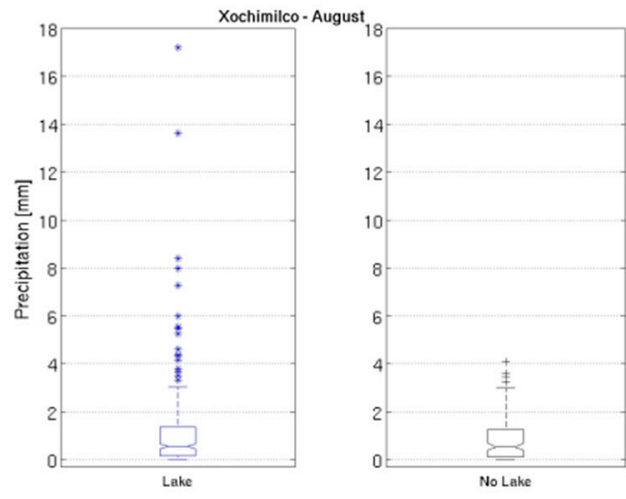

(b)

Figure 11. Box plots of the hourly precipitation $(>0.005 \mathrm{~mm} / \mathrm{h})$ in Tenochtitlán (a) and Xochimilco (b) with L/WRFc (left) and with NL/WRFc (right) during the month of August. (No-Lake: NL/WRFc; Lake: L/WRFc.)

Although the area of ancient lake system of the Valley of Mexico was relatively small, $1500 \mathrm{~km}^{2}$ [6,24], these results show a strong impact on the local precipitation, DTR, and mixed layer height due to its desiccation. These impacts on the local micro-climate may be increased by the relative isolation of the valley because it is surrounded by mountains. The former lake-land-mountain breeze mechanism has been completely modified and only the valley-mountain breeze remains. Figures 6 and 7 show shifts in precipitation and temperature maxima which are associated with a very different characteristic time for the heat fluxes, suggesting that in the simulations with a lake system the valley-lake breeze commences later than it does when no lake is present. Additionally, lake breeze plus mountain-valley breeze modify the convergence zones, where moisture fluxes with background water vapor favor precipitation to the southwest $[14,15,46]$.

The experiments show an increase in precipitation with the presence of the ancient lake system consistent with previous studies regarding the effect of lakes on regional climate [2]. For an extra-tropical experiment in the Great Lakes, Reference [2] showed an increase in evaporation and precipitation due to the presence of the lakes during autumn and winter. In [10], authors showed that, for the Mexico City, the increase in precipitation over the last 30 years is mainly due to the increase in aerosols. They found that including a modified version of aerosols physics in WRF is possible to model the most recent changes in precipitation. Joining our results with those obtained by [10] suggests that regional changes in precipitation for the Mexico City Basin are a combination of the land use change and a quite complex urban growth.

\section{Conclusions}

This study shows the changes in precipitation and other variables due to LULCCs in the Mexico City Basin. For over 500 years, the ancient lake system underwent extreme modifications which led to its disappearance. While the ancient lake system was going extinct, a rather fast urbanization growth occurred. These changes modified the surface fluxes, resulting in a regional microclimate which is rather different from the milder climate that used to be in the past.

Our results show that there is a decrease in precipitation due to the removal of the lake system; however, the transition between the lake removal and the increase in urbanization seems to contribute in two different ways. On the one hand, considering only the desiccation of the lake results in a reduction of precipitation, as shown in this work. On the other hand, the excess of aerosols resulting from the rapid urbanization growth favors nucleation and therefore increases precipitation [10].

The simulations performed here do not include an increase in atmospheric aerosols, which has been shown to be partially responsible for the increase in precipitation that is currently happening in 
Mexico City. Without this effect, the difference in precipitation between the experiments without and with a lake (calculated by results with no lake minus those with a lake) results in a decrease due to the lake desiccation. Additionally, we show that the lake physics determines whether the precipitation increases or decreases. The desiccation of the lake and the urbanization growth in Mexico City occurred simultaneously but accelerated over the last 150 years. These two processes still remain as a research topic, which is being explored by the authors and colleagues.

The performance of regional numerical models depends on the LSMs, which solve the soil-vegetation-atmosphere interactions [47]; drastic changes on the land surface from human activities modify those interactions at the regional scale or even at smaller scales. The work presented in this paper shows, at a regional level, the meteorological impacts as a consequence of drastic changes in land cover. However, their reversible changes on land use and their impact on the local economy and ecosystems need further investigation. On our planet, there are several locations in danger of drying out in a similar way as those that are currently disappearing, e.g., the Aral Sea [12], Lake Poopó [48], and Chad Lakes [49].

According to the IPCC 2013 Report, the regional LULCC complicates the interpretation of a large DTR in large-scale models; thus, additional studies could provide the proper parameterization to be captured in those models $[50,51]$. The experiment with a lake implies a more evenly distributed precipitation and an increase in total accumulated precipitation, which modifies the soil moisture regionally. Even at a first approximation, changes in the moisture content of soils results in a different surface heat flux balance. Meteorological properties, such as air temperature and PBLH, are regionally and locally changed and these processes are not properly represented by large-scale global circulation models due to their limitations in temporal and spatial resolution.

Different commitments can be taken for the future of the valley. Nevertheless, the current trend of expanding the area of the city at the expense of the remaining wetlands may worsen the weather patterns shown here. Some options, as the recovery of part of the lake and the establishment of green areas, may revert to this tendency. The quality of life can be better in a region with a moderate climate. On the other hand, migrating towards more extreme microclimates also affects the economy and energy consumption, since the use of air conditioning and heaters may be increased. These issues need to be considered by policy-makers in this and other cities where regional climate has been strongly affected by anthropogenic activities.

Author Contributions: Conceptualization, A.R.-A. and E.L.-E.; data curation, E.L.-E., A.R.-A., and J.E.-S.; methodology, E.L.-E. and A.R.-A.; formal analysis, A.R.-A., E.L.-E., J.Z.-H., and R.R.-C.; writing of original draft preparation, A.R.-A., E.L.-E., and J.E.-S.; writing of review and editing, E.L.-E., A.R.-A., J.Z.-H., and R.R.-C.; supervision, A.R.-A.,E.L.-E., J.Z.-H., and R.R.-C.

Funding: This research was funded by Universidad Nacional Autónoma de México, Dirección General de Asuntos del Personal Académico (grant numbers: IA100915, IA101614, and IA101813).

Acknowledgments: We acknowledge to the Universidad Nacional Autónoma de Mexico for the use of the supercomputer Miztli and the support to DGTIC. We also like to thank Octavio Gómez Ramos for his technical assistance and Oscar Jurado de Larios for helpful comments.

Conflicts of Interest: The authors declare no conflict of interest.

\section{References}

1. Huang, A.; Wang, J.; Dai, Y.; Yang, K.; Wei, N.; Wen, L.; Wu, Y.; Zhu, X.; Zhang, X.; Cai, S. Evaluating and improving the performance of Three 1-D lake models in a large deep lake of the Central Tibetan Plateau. J. Geophys. Res. Atmos. 2019, 124, 3143-3167. [CrossRef] [PubMed]

2. Notaro, M.; Holman, K.; Zarrin., A.; Fluck, E.; Vavrus, S.; Bennington, V. Influence of the Laurentian Great Lakes on regional climate. J. Clim. 2013, 26, 789-804. [CrossRef]

3. Ruiz-Angulo, A.; López-Espinoza, E. Estimación de la respuesta térmica de la cuenca lacustre del Valle de México en el siglo XVI: Un experimento numérico. Bol. Soc. Geol. Mex. 2015, 67, 215-225. [CrossRef]

4. Xu, L.; Liu, H.; Du, Q.; Wang, L. Evaluation of the WRF-lake model over a highland freshwater lake in southwest China. J. Geophys. Res. Atmos. 2016, 121, 13-989. [CrossRef] 
5. Oke, T.; Spronken-Smith, R.; Jáuregui, E.; Grimmond, C. The energy balance of central Mexico City during the dry season. Atmos. Environ. 1999, 33, 3919-3930. [CrossRef]

6. Jazcilevich, A.; Fuentes, V.; Jauregui, E.; Luna, E. Simulated urban climate response to historical land use modification in the basin of Mexico. Clim. Chang. 2000, 44, 515-536. [CrossRef]

7. Jáuregui, E. Heat island development in Mexico City. Atmos Environ. 1997, 31, 3821-3831. [CrossRef]

8. Jáuregui, E. Impact of land-use changes on the climate of the Mexico City Region. Investig. Geogr. 2004, 55, 46-60. [CrossRef]

9. Jáuregui, E.; Romales, E. Urban effects on convective precipitation in Mexico City. Atmos Environ. 1996, 30, 3383-3389. [CrossRef]

10. Ochoa, C.; Quintanar, A.; Raga, G.; Baumgardner, D. Changes in intense precipitation events in Mexico City. J. Hydrometeorol. 2015, 16, 1804-1820. [CrossRef]

11. Gu, H.; Shen, X.; Jin, J.; Xiao, W.; Wang, Y.W. An application of a 1-D thermal diffusion lake model to Lake Taihu. Acta Meteorol. Sin. 2013, 71, 719-730.

12. Sharma, A.; Huang, H.; Zavialov, P.; Khan, V. Impact of desiccation of Aral Sea on the regional climate of Central Asia using WRF model. Pure. Appl. Geophys. 2018, 175, 465-478. [CrossRef]

13. Ma, Y.; Yang, Y.; Qiu, C.; Wang, C. Evaluation of the WRF-lake model over two major freshwater lakes in China. J. Meteorol. Res. 2019, 33, 219-235. [CrossRef]

14. Koseki, S.; Mooney, P.A. Influences of Lake Malawi on the spatial and diurnal variability of local precipitation. Hydrol. Earth Syst. Sci. 2019, 23, 2795-2812. [CrossRef]

15. Diallo, I.; Giorgi, F.; Stordar, F. Influence of Lake Malawi on regional climate from a double-nested regional climate model experiment. Clim. Dyn. 2018, 50, 3397-3411. [CrossRef]

16. Mallard, M.; Nolte, C.; Spero, T.; Bullock, O.; Alapaty, K.; Herwehe, J.; Gula, J.; Bowden, J. Technical challenges and solutions in representing lakes when using WRF in downscaling applications. Geosci. Model. Dev. 2015, 8, 1085-1096. [CrossRef]

17. Gu, H.; Jin, J.; Wu, Y.; Ek, M.B.; Subin, Z.M. Calibration and validation of lake surface temperature simulations with the coupled WRF-lake model. Clim. Chang. 2015, 129, 471-483. [CrossRef]

18. Benson-Lira, V.; Georgescu, M.; Kaplan, S.; Vivoni, E. Loss of a lake system in a megacity: The impact of urban expansion on seasonal meteorology in Mexico City. J. Geophys Res. Atmos. 2016, 121, 3079-3099. [CrossRef]

19. Sanders, W.; Parsons, J.; Santley, R. The Basin of Mexico: Ecological Processes in the Evolution of A Civilization; Academic Press: New York, NY, USA, 1979.

20. Lozano-García, M.; Ortega-Guerrero, B.; Caballero-Miranda, M.; Urrutia-Fucugauchi, J. Late Pleistocene and Holocene paleoenvironments of Chalco lake, central Mexico. Quat. Res. 1993, 40, 332-342. [CrossRef]

21. Tolstoy, P.; Fish, S.; Boksenbaum, M.; Vaughn, K.; Smith, C. Early sedentary communities of the Basin of Mexico. J. Field Archaeo. 1977, 4, 91-106. [CrossRef]

22. Ezcurra, E. De las Chinampas a la Megalópolis: El Medio Ambiente en la Cuenca de México; Fondo de Cultura Económica: Ciudad de Mexico, Mexico, 1990.

23. Niederberger-Betton, C. Paléopaysages et Archéologie pre-Urbaine du Bassin de Mexico; Centre D'études Mexicaines et Centraméricaines: Ciudad de Mexico, Mexico, 1987.

24. Endfield, G. Climate and Society in Colonial Mexico: A Study in Vulnerability; Wiley-Blackwell: Chicester, UK, 2011.

25. García, E. Situaciones climáticas durante el auge y la caída de la cultura teotihuacana. Investig. Geogr. 1974, 5, 35-69. [CrossRef]

26. Jáuregui, E. Effects of revegetation and new artificial water bodies on the climate of northeast Mexico City. Energy Build. 1974, 15, 447-455. [CrossRef]

27. Mas, J.; Velázquez, A.; Díaz-Gallegos, J.; Mayorga-Saucedo, R.; Alcántara, C.; Bocco, G.; Castro, R.; Fernández, T.; Pérez-Vega, A. Assessing land use/cover changes: A nationwide multidate spatial database for Mexico. Int. J. Appl Earth Obs. Geoinf. 2004, 5, 249-261. [CrossRef]

28. López-Bravo, C.; Caetano, E.; Magaña, V. Forecasting summertime surface temperature and precipitation in the Mexico City metropolitan area: Sensitivity of the WRF model to land cover changes. Front. Earth Sci. 2018, 6, 6. [CrossRef]

29. Lafragua, J.; Gutiérrez, A.; Aguilar, E.; Aparicio, J.; Mejía, R.; Santillan, O.; Suárez, M.A.; Preciado, M. Balance hídrico del valle de México. In Anuario 2003; Gómez, M.A., Cruz, F., Wagner, A.I., Pineda, V.M., Requejo, A., 
Robles, B., Villavicencio, F.J., Eds.; Instituto Mexicano de Tecnología del Agua: Jiutepec, Mexico, 2003; pp. 40-46, ISBN-968-5536-38-4.

30. Meza-Carreto, J. Evaluación del Desempeño del Modelo WRF para Reproducir las Variaciones de la Temperatura en México durante la Década de los 80. Master's Thesis, Universidad Nacional Autónoma de México, Ciudad de Mexico, Mexico, 12 November 2018.

31. López-Méndez, V. Análisis del Evento Meteorológico Relacionado con la Inundación de Tabasco del 2009. Master's Thesis, Universidad Nacional Autónoma de México, Ciudad de Mexico, Mexico, 30 June 2009.

32. Jurado de Larios, O.E. Sensibilidad del Modelo WRF ante Condiciones Iniciales y de Frontera: Un Estudio de Caso en el Valle de México. Master's Thesis, Universidad Nacional Autónoma de México, Ciudad de Mexico, Mexico, 27 June 2017.

33. López-Espinoza, E.D.; Zavala-Hidalgo, J.; Mahmood, R.; Gómez-Ramos, O. Assessing the Land Use and Land Cover Data Representation on Weather Forecast Quality: A Case Study in central Mexico. Meteorol. Atmos. Phys. under review.

34. Reporte del Clima en México. Available online: https://smn.conagua.gob.mx/es/climatologia/diagnosticoclimatico/reporte-del-clima-en-mexico (accessed on 7 September 2019).

35. Meteorología/Grupo Interacción Océano-Atmósfera. Available online: http://grupo-ioa.atmosfera.unam.mx/ pronosticos/index.php/meteorologia (accessed on 11 September 2019).

36. Kalnay, E. Atmospheric Modeling, Data Assimilation and Predictability; Cambridge University Press: New York, NY, USA, 2003.

37. Kain, J. The Kain-Fritsch convective parameterization: An update. J. Appl. Meteorol. 2004, 43, $170-181$. [CrossRef]

38. Skamarock, W.; Klemp, J.; Dudhia, J.; Gill, D.; Barker, D.; Wang, W.; Powers, J. A Description of the advanced research WRF version 2. NCAR Tech. Note 2005, 468. [CrossRef]

39. Zhang, Y.; Dubey, M.K.; Olsen, S.C.; Zheng, J.; Zhang, R. Comparisons of WRF/Chem simulations in Mexico City with ground-based RAMA measurements during the 2006-MILAGRO. Atmos. Chem. Phys. 2009, 9, 3777-3798. [CrossRef]

40. Chen, F.; Dudhia, J. Coupling an advanced land surface-hydrology model with the Penn State-NCAR MM5 modeling system. Part I: Model implementation and sensitivity. Mon. Weather Rev. 2001, 129, 569-585. [CrossRef]

41. Loveland, T.; Reed, B.; Brown, J.; Ohlen, D.; Zhu, Z.; Yang, L.; Merchant, J. Development of a global land cover characteristics database and IGBP DISCover from $1 \mathrm{~km}$ AVHRR data. Int. J. Remote Sens. 2000, 21, 1303-1330. [CrossRef]

42. Oleson, K.; Lawrence, D.; Gordon, B.; Flanner, M.; Kluzek, E.; Peter, J.; Levis, S.; Swenson, S.; Thornton, E.; Feddema, J.; et al. Technical description of version 4.0 of the Community Land Model (CLM). NCAR Tech. Note 2010, 478. [CrossRef]

43. Subin, Z.; Riley, W.; Mironov, D. An improved lake model for climate simulations: Model structure, evaluation, and sensitivity analyses in CESM1. J. Adv. Model. Earth Syst. 2012, 4, 1-27. [CrossRef]

44. Thiery, W.; Stepanenko, V.; Fang, X.; Jöhnk, K.; Li, Z.; Martynov, A.; Perroud, M.; Subin, Z.; Darchambeau, F.; Mironov, D.; et al. LakeMIP Kivu: Evaluating the representation of a large, deep tropical lake by a set of one-dimensional lake models. Tellus A Dyn. Meteorol. Oceanogr. 2014, 66, 21390. [CrossRef]

45. Raynal-Villasenor, J.A. The Remarkable Hydrological Works of the Aztec Civilization. Available online: http://hydrologie.org/redbooks/a164/iahs_164_0003.pdf (accessed on 7 September 2019).

46. Cosgrove, A.; Berkelhammer, M. Downwind footprint of an urban heat island on air and lake temperatures. NPJ Clim. Atmos Sci. 2018, 1, 46. [CrossRef]

47. Koster, R.; Suarez, M.; Liu, P.; Jambor, U.; Berg, A.; Kistler, M.; Reichle, R.; Rodell, M.; Famiglietti, J. Realistic initialization of land surface states: Impacts on subseasonal forecast skill. J. Hydrometeorol. 2004, 5, 1049-1063. [CrossRef]

48. Zola, R.; Bengtsson, L. Long-term and extreme water level variations of the shallow Lake Poopó, Bolivia. Hydrol. Sci. J. 2006, 51, 98-114. [CrossRef]

49. Lauwaet, D.; Van Lipzig, N.; Van Weverberg, K.; De Ridder, K.; Goyens, C. The precipitation response to the desiccation of Lake Chad. Q. J. R. Meteorol. Soc. 2012, 138, 707-719. [CrossRef] 
50. Hartmann, D.; Tank, A.; Rusticucci, M.; Alexander, L.; Brönnimann, B.; Charabi, Y.; Dentener, F.; Dlugokencky, E.; Easterling, D.; Kaplan, A.; et al. Observations: Atmosphere and Surface. Climate Change 2013 the Physical Science Basis: Working Group I Contribution to the Fifth Assessment Report of the Intergovernmental Panel on Climate Change; Cambridge University Press: New York, NY, USA, 2013.

51. Thiery, W.; Davin, E.L.; Seneviratne, S.I.; Bedka, K.; Lhermitte, S.; Van Lipzig, N.P. Hazardous thunderstorm intensification over Lake Victoria. Nat. Commun. 2016, 7, 12786. [CrossRef]

C 2019 by the authors. Licensee MDPI, Basel, Switzerland. This article is an open access article distributed under the terms and conditions of the Creative Commons Attribution (CC BY) license (http://creativecommons.org/licenses/by/4.0/). 